DOI: $10.20472 / E S .2018 .7 .2 .005$

\title{
DETERMINANTS OF THE GOVERNMENT BOND YIELD: EVIDENCE FROM A HIGHLY EUROISED SMALL OPEN ECONOMY
}

\author{
MAJA MIHELJA ŽAJA, DRAGO JAKOVČEVIĆ, LUCIJA VIŠIĆ
}

\begin{abstract}
:
This paper analyses the relationship between bond market, macroeconomic fundamentals and a set of additional covariates in the Republic of Croatia, a small open economy with a very high and persistent level of euroization. The sample ranges from the year 2001 to 2017. Ordinary least squares regression is applied on the quarterly dataset to examine the major drivers of nominal yields of government bonds, whereas Multiple Breakpoint Tests are used to determine structural breaks in the variables. The results corroborate theoretical knowledge and suggest a significant effect of fiscal and financial determinants on bond yields. Variables presenting macroeconomic fundamentals explain a substantial part of Croatian trends. Therefore, policymakers seeking to improve macroeconomic conditions should learn from multi-causal studies involving these variables before setting their policies.
\end{abstract}

\section{Keywords:}

government bonds, macroeconomic fundamentals, structural changes, linear regression, The Republic of Croatia

JEL Classification: C32, E44, G12

\section{Authors:}

MAJA MIHELJA ŽAJA, Faculty of Economics and Business Zagreb, Croatia, Email:

mmiheljaz@net.efzg.hr

DRAGO JAKOVČEVIĆ, Faculty of Economics and Business Zagreb, Croatia, Email:

djakovcevic@efzg.hr

LUCIJA VIŠIĆ, Faculty of Economics and Business Zagreb, Croatia, Email: visiclucija@gmail.com

\section{Citation:}

MAJA MIHELJA ŽAJA, DRAGO JAKOVČEVIĆ, LUCIJA VIŠIĆ (2018). Determinants of the Government Bond Yield: Evidence from a Highly Euroised Small Open Economy. International Journal of Economic Sciences, Vol. VII(2), pp. 87-106., 10.20472/ES.2018.7.2.005 


\section{Introduction}

Many researchers suggest that macroeconomic fundamentals determine the cost of government borrowing. Consequently, the public debt is a major area of observation, especially in the new EU members. Governments may accumulate public debt to support public needs, for example by public spending on education and healthcare.

The Republic of Croatia, an economy with high public debt and budget deficits, is suffering consequences of irresponsible fiscal and budgetary policies that country has been conducting for decades. The main problem is that governments with above-average deficits and debt will find that they have less financial flexibility. With the increase in public debt financing by issuing bonds on the one side, and increasing the investor's interest in investing in the other, the question is how certain macroeconomic variables affect their value. The aim of this paper is to provide a better understanding of major determinants that have an impact on the yield of government bonds as a significant instrument in resolving fiscal issues in the Republic of Croatia. Previous studies have shown that not only macroeconomic fundamentals have an impact on determining government bond yields, but also external factors should be taken into consideration. In the last decade, two main factors geared the empirical research towards the examination of the determinants of government bond yields. The first was the inception of the European Monetary Union (EMU) and the second the global financial crisis of 2008 (Chionis, Pragidis, Schizas, 2014).

The empirical part of the paper consists of standard multiple linear regression models with $\mathrm{T}$ periods and $\mathrm{m}$ potential breaks using government bonds yield as the dependent variable and 19 independent variables. These variables include data for main macroeconomic, financial, fiscal and political indicators. This paper investigates the variations in the given results during four different periods: before the crisis, during the financial crisis, after the recession, and the recovery period.

Contributions of our paper are twofold. First, our analysis aims to explore various macroeconomic, financial, fiscal and political indicators that could be significant in determining government bond yield. According to the studied literature, many papers are examining the relationship between government bond yields and various determinants in a case of a single economy. However, to our best knowledge, there are no papers that take into account 19 various macroeconomic, financial, fiscal and political indicators together in explaining the reasons for the relatively high price of a country's debt in the Republic of Croatia. Second, the influence of these variables was explored in four periods according to the "structural" break in the data which enabled us to see which variable outweighed given the economic situation in the country. Multiple or structural breaks can be present in the trend function of different economic time series and may overlap with detectable fiscal, economic, political and climatic shocks. 
This paper is organized as follows. The development of Croatian bond market and the analysis of the current condition on the bond market is given in Chapter 2. Empirical methodology and data are described in Chapter 3 . The results of the econometric analysis are reported in Chapter 4, and the conclusion is provided in Chapter 5.

\section{Background and literature review}

Croatian government bonds are medium to long-term bonds issued by the public sector. The central government, counties, and municipalities use government bonds to finance long-term governmental infrastructure projects like road and railway construction, education and healthcare, but also for the financing budget deficit and refinancing the existing government debt. They are a financial instrument with the highest rating and security issued by the Croatian government based on the recommendation of the Ministry of Finance based on the annual release plan. Once being issued, they are included in the first quotation of the Zagreb Stock Exchange. There are numerous benefits of the development of an efficient and transparent government bond market both in developed and emerging financial markets (Prohaska, Olgić Draženović, 2010): it is a source for financing deficits at lower costs, strengthening the transmission and implementation of central bank's monetary policy, reducing exposure to interest rate, currency and other financial risks, increasing of financial stability, and improving the financial intermediation. Yields on government bonds represent benchmarks in determining prices of publishing corporate bonds, but also other financial instruments on the market.

\subsection{The development of the Croatian bond market}

The Croatian bond market was created in 2000 when the Croatian Health Insurance Institute ( $\mathrm{HZZO}$ ) issued bonds for EUR 222 million for its consolidation. A few months afterward, the State Agency for Deposit Insurance and Bank Rehabilitation (DAB) for repairing the banking system issued bonds with maturities of 2003 and 2005 in the amount of 105 and 225 million euros. At that point, Croatian secondary market was illiquid since it did not exist. The reasons for this were numerous: peace in the country was recently established, the low credit rating of the country, the lack of tradition and expertise for capital market operations. However, the most significant cause was the absence of notable institutional investors that would contribute to the development of the secondary market. The secondary market of individual issues at that point was supported by banks that arranged the issue. They did so until the Croatian Banking Association (HUB) created the so-called "Zibor group" market maker with the purpose of simplifying portfolio valuation (HANFA, 2010).

The real progress of the Croatian bond market is related with the pension reform initiated at the end of 2001. This reform introduced the system of capitalized savings along with the existing system of intergenerational solidarity. The reform of the pension system, apart from the primary goal of solving the retirement issue as a social component, had a significant 
impact on the development of the Croatian capital market, especially the bond market (HANFA, 2010). Since then, pension funds have been considered as a vital factor of the demand side. The existing legal framework regulating financial markets has been improved by the adoption of the Securities Market Act (ZTVP NN 84/02) in 2002. In 2005, the difference between Euro and Kuna interest yields decreased, and the country, to reduce foreign debt, was indebted at the domestic market to finance the budget deficit. This borrowing in 2005, resulted in the emergence of Kuna releases, and pension and investment funds were increasingly involved.

During 2006 corporations turned to the capital market by issuing bonds what lead to the phase of significant Kuna denominated corporate releases. Investment funds became essential investors and contributed to increased liquidity (HANFA, 2010). Due to such sequence of events, this period is called the golden age of the Croatian bond market. In 2007 the financial crisis begun to spread, including the Croatian capital market. Emerging markets such as Croatian have been more affected by the crisis due to investors' mistrust and problematic liquidity. In 2008, a new Law on Capital Market was adopted (ZTK NN 146/08), which harmonized domestic legislation with EU regulations. Stabilization of the situation in the global financial markets provided prerequisites for the revival of the domestic bond market, and in the second half of 2009, there was a gradual recovery of trust at emerging markets (HANFA, 2010). In the third quarter of 2009, the demand for government bonds was re-established, which is mainly the merit of mandatory pension funds (HANFA, 2010). In the subsequent period from 2010, the Croatian government continued with the issuing of the bonds on the foreign and domestic market. Although this market is considerably more stable than in 2002 , it is still poorly developed compared to other EU member states, and the volume of trading has not returned to the pre-crisis level.

\subsection{The analysis of the issuance of Croatian Government Bonds}

As already mentioned, government bonds are issued when the Ministry of Finance hands out a proposal on issuing the bonds to the Government, after which it makes a decision. In the Republic of Croatia, the current practice of issuing bonds has been through domestic business banks that appear as agents or issuers, and the bank whose offer is the best is chosen. The schedule of future issues is mainly related to the maturity of issued bonds, which are mostly repayable by the issue of new ones, but also depends on the market demand.

Bonds before the adoption of the pension reform until 2002 were not traded substantially, and most of the trading took place through direct trading and beyond an organized market. The reason for this is the high costs of brokerage and commissions on the stock exchange. (Dragič, Lamza, 2004).

Table 1 Croatian government bonds issued on domestic and international markets (1996-2017) 


\begin{tabular}{|c|c|c|c|c|c|c|}
\hline Symbol & Issuer & $\begin{array}{c}\text { Amount } \\
\text { (mil) }\end{array}$ & Currency & Release Date & Due date & $\begin{array}{l}\text { Interest rate } \\
(\%)\end{array}$ \\
\hline London Club Seria A & $\mathrm{RH}$ & 875,796 & USD & 31.07.1996. & 31.07 .2010$. & * \\
\hline London Club Seria B & $\mathrm{RH}$ & 604,426 & USD & 31.07.1996. & 31.07.2006. & * \\
\hline Euro-dollar bonds & $\mathrm{RH}$ & 300 & USD & 06.02.1997. & 27.02.2002. & $7 \%$ \\
\hline Euro-DEM bonds & $\mathrm{RH}$ & 300 & USD & 01.07.1997. & 16.07.2004. & $6,125 \%$ \\
\hline Matador bonds & $\mathrm{RH}$ & 15000 & ESP & 04.03.1998. & 26.03 .2001$. & $6,50 \%$ \\
\hline Euro-EUR bonds/l & $\mathrm{RH}$ & 300 & EUR & 23.02.1999. & 10.03.2006. & $7,375 \%$ \\
\hline Samurai bond/l & $\mathrm{RH}$ & 25000 & JPY & 14.12.1999. & 14.12.2004. & $4 \%$ \\
\hline Euro-EUR bonds/II & $\mathrm{RH}$ & 500 & EUR & 28.03 .2000$. & 28.03.2005. & $7 \%$ \\
\hline Samurai bond/II & $\mathrm{RH}$ & 40000 & JPY & 11.07.2000. & 11.07.2007. & $3 \%$ \\
\hline DAB-O-03CA & $\mathrm{DAB}$ & 105 & EUR & 19.12.2000. & 19.12.2003. & $8 \%$ \\
\hline DAB-O-05CA & DAB & 225 & EUR & 19.12.2000. & 19.12.2005. & $8,375 \%$ \\
\hline HZZO-O-047A & $\mathrm{HZZO}$ & 222 & EUR & 19.07.2000. & 19.07.2004. & $8,50 \%$ \\
\hline Samurai bond/III & $\mathrm{RH}$ & 25000 & JPY & 06.02.2001. & 23.02.2006. & $2,50 \%$ \\
\hline Euro-EUR bonds/III & $\mathrm{RH}$ & 750 & EUR & 06.03.2001. & 14.03.2011. & $6,75 \%$ \\
\hline RHMF-O-049A & $\mathrm{RH}$ & 200 & EUR & 20.09 .2001$. & 20.09 .2004$. & $6,50 \%$ \\
\hline RHMF-O-08CA & $\mathrm{RH}$ & 200 & EUR & 14.12 .2001$. & 14.12.2008. & $6,875 \%$ \\
\hline Euro-EUR bonds/IV & $\mathrm{RH}$ & 500 & EUR & 28.01 .2002$. & 11.02.2009. & $6,25 \%$ \\
\hline RHMF-O-125A & $\mathrm{RH}$ & 500 & EUR & 12.05.2002. & 23.05.2012. & $6,875 \%$ \\
\hline Samurai bond/IV & $\mathrm{RH}$ & 25000 & JPY & 26.06 .2002 . & 26.06 .2008$. & $2,15 \%$ \\
\hline Euro-EUR bondsIV & $\mathrm{RH}$ & 500 & EUR & 24.02 .2003$. & 24.02.2010. & $4,63 \%$ \\
\hline RHMF-O-085A & $\mathrm{RH}$ & 1000 & HRK & 28.05.2003. & 28.05.2008. & $6,125 \%$ \\
\hline Samurai bond/V & $\mathrm{RH}$ & 25000 & JPY & 26.06.2003. & 26.06.2009. & $1,23 \%$ \\
\hline RHMF-O-142A & $\mathrm{RH}$ & 650 & EUR & 10.02.2004. & 10.02.2014. & $5,50 \%$ \\
\hline Euro-EUR bonds/VI & $\mathrm{RH}$ & 500 & EUR & 15.04 .2004$. & 15.04.2014. & $5 \%$ \\
\hline RHMF-O-077A & $\mathrm{RH}$ & 400 & EUR & 07.07.2004. & 07.07.2007. & $3,875 \%$ \\
\hline RHMF-O-19BA & $\mathrm{RH}$ & 1000 & EUR & 29.11 .2004$. & 19.11.2019. & $5,375 \%$ \\
\hline RHMF-O-103A & $\mathrm{RH}$ & 3000 & HRK & 08.03.2005. & 08.03.2010. & $6,75 \%$ \\
\hline RHMF-O-157A & $\mathrm{RH}$ & 350 & EUR & 14.07.2005. & 14.07.2015. & $4,25 \%$ \\
\hline RHMF-O-15CA & $\mathrm{RH}$ & 5500 & HRK & 15.12.2005. & 15.12.2015. & $5,25 \%$ \\
\hline RHMF-O-137A & $\mathrm{RH}$ & 4000 & HRK & 11.07.2006. & 11.07.2013. & $4,50 \%$ \\
\hline RHMF-O-172A & $\mathrm{RH}$ & 5500 & HRK & 08.02.2007. & 08.02.2017. & $4,75 \%$ \\
\hline Euro-EUR bonds/VII & $\mathrm{RH}$ & 750 & EUR & 05.06.2009. & 05.01.2015. & $6,50 \%$ \\
\hline Euro-USD bonds/l & $\mathrm{RH}$ & 1500 & USD & 05.11 .2009$. & 05.11 .2019$. & $6,75 \%$ \\
\hline RHMF-O-203A & $\mathrm{RH}$ & 5000 & HRK & 05.03.2010. & 05.03.2020. & $6,75 \%$ \\
\hline RHMF-O-203E & $\mathrm{RH}$ & 1000 & EUR & 05.03.2010. & 05.03.2020. & $6,50 \%$ \\
\hline Euro-USD bonds/II & $\mathrm{RH}$ & 1250 & USD & 14.07.2010. & 14.07.2020. & $6,625 \%$ \\
\hline RHMF-O-17BA & $\mathrm{RH}$ & 4000 & HRK & 25.11.2010. & 25.11 .2017$. & $6,25 \%$ \\
\hline Euro-USD bonds/III & $\mathrm{RH}$ & 1500 & USD & 24.03.2011. & 24.03.2021. & $6,375 \%$ \\
\hline Euro-EUR bonds/VIII & $\mathrm{RH}$ & 750 & EUR & 08.07.2011. & 09.07.2018. & $5,875 \%$ \\
\hline RHMF-O-167A & $\mathrm{RH}$ & 3500 & HRK & 22.07.2011. & 22.07.2016. & $5,75 \%$ \\
\hline RHMF-O-227E & $\mathrm{RH}$ & 1000 & EUR & 22.07 .2011$. & 22.07 .2022$. & $6,50 \%$ \\
\hline Euro-USD bonds/IV & $\mathrm{RH}$ & 1500 & USD & 27.04.2012. & 27.04.2017. & $6,25 \%$ \\
\hline Euro-USD bonds/V & $\mathrm{RH}$ & 1500 & USD & 04.04.2013. & 04.04.2023. & $5,50 \%$ \\
\hline RHMF-O-187A & $\mathrm{RH}$ & 6000 & HRK & 10.07.2013. & 10.07.2018. & $5,25 \%$ \\
\hline RHMF-O-247E & $\mathrm{RH}$ & 1400 & EUR & 10.07.2013. & 10.07.2024. & $5,75 \%$ \\
\hline Euro-USD bonds/VI & $\mathrm{RH}$ & 1750 & USD & 26.11 .2013$. & 26.01 .2024 . & $6 \%$ \\
\hline Euro-EUR bonds/IX & $\mathrm{RH}$ & 1250 & EUR & 29.05.2014. & 30.05.2022. & $3,875 \%$ \\
\hline Euro-EUR bonds/X & $\mathrm{RH}$ & 1500 & EUR & 11.03.2015. & 11.03.2025. & $3 \%$ \\
\hline
\end{tabular}




\begin{tabular}{|c|c|c|c|c|c|c|}
\hline RHMF-O-257A & $\mathrm{RH}$ & 6000 & HRK & 09.07 .2015$. & 09.07 .2025$. & $4,50 \%$ \\
\hline RHMF-O-26CA & $\mathrm{RH}$ & 10000 & HRK & 14.12 .2015$. & 14.12 .2026$. & $4,25 \%$ \\
\hline RHMF-O-217A & $\mathrm{RH}$ & 6000 & HRK & 08.07 .2016$. & 08.07 .2021$. & $2,75 \%$ \\
\hline RHMF-O-222A & $\mathrm{RH}$ & 3000 & HRK & 07.02 .2017$. & 07.02 .2022$. & $2,25 \%$ \\
\hline RHMF-O-282A & $\mathrm{RH}$ & 5500 & HRK & 07.02 .2017$. & 07.02 .2028$. & $2,875 \%$ \\
\hline Euro-EUR bonds/XI & $\mathrm{RH}$ & 1250 & EUR & 20.03 .2017$. & 20.03 .2027$. & $3 \%$ \\
\hline RHMF-O-327A & $\mathrm{RH}$ & 3000 & HRK & 07.07 .2017$. & 07.07 .2032$. & $3,25 \%$ \\
\hline RHMF-O-23BA & $\mathrm{RH}$ & 11300 & HRK & 27.11 .2017$. & 27.11 .2023$. & $1,75 \%$ \\
\hline Euro-EUR bonds/XII & $\mathrm{RH}$ & 1275 & EUR & 27.11 .2017$. & 27.01 .2030$. & $2,75 \%$ \\
\hline
\end{tabular}

Source: Authors' according to Zagreb Stock Exchange and Croatian National Bank

Bonds issued by Croatian government on domestic and foreign markets are listed in Table 1. The first issued bonds were in 1996 in USD with the maturity of 10 and 14 years. First domestic bond was issued in 2000 by Croatian Health Insurance Institute (HZZO) denominated in Euros with a maturity of four years. Until 2003 bonds were denominated in foreign currencies (USD, ESP, EUR, JPY), with a maturity of 3, 5, 7, 10 years and with the range of coupon from $6,5 \%-8,5$ for domestic issues and $2,15 \%-7,375 \%$ for foreign issues. In 2003, government issues first bonds denominated in domestic currency with interest rate of $6,125 \%$ and maturity of five years. Although every issued series is specific and is determined with different factors, during years interest rates are declining, and maturity becomes longer. Interest rate for domestic bonds range from 1,75\% in 2017 (RHMF-O23BA) to $8,5 \%$ in 2000 (HZZO-O-047A), and for foreign bonds range from 1,23\% (Samurai bond/V) in 2003 to $7,375 \%$ (Euro-EUR bonds/l) in 1999. The average interest rate is $5,375 \%$ on domestic and $5,08 \%$ on foreign issues what is relatively high and is connected with the non-investment credit rating and negative perception on the Republic of Croatia on the international market.

It is essential to point out that in the period from 2007 to 2010 there were no issues of government bonds on the domestic market and from 2005 to 2009 in the foreign markets. This situation on the capital market was a consequence of the global financial crisis that affected the Croatian capital market. It is evident that the state has departed from the precrisis targets set out in the Annual Report and the Public Debt Management Strategy, that is, from the targeted expansion of the investor base and the development of the domestic debt securities market by issuing HRK bonds of different maturity and creating a yield curve. During this period, the government primarily use treasury bills and syndicated loans for financing. From 2009, the Republic of Croatia had 12 issues on the foreign market and 14 on the domestic market. It is evident that the government accumulates part of the required capital on the domestic market, thus contributing to the expansion of the domestic bond market, and an indicator of development is the growing activity of the same on the secondary market. 


\subsection{Related Research on the Determinants of Government Bond Yields}

The empirical literature on determinants of government bond yields can be divided into two parts: time-series analyses of a single economy and panel data analyses. Single-country studies employ time series regression methods to analyze the impact of fundamentals on government borrowing costs. In addition to stock and flow fiscal variables (debt and deficit, respectively), the reduced form equations typically include additional controls, such as short-term interest rates (determined by monetary policy and therefore considered exogenous), inflation, money growth and other (Poghosyan, 2014).

Pirtea, Nicolescu, and Mota (2013) among the others, examined the dynamics of public debt in Romania in the period 2000 to 2011 . The model discovered significant primary fiscal balance, the real GDP growth rate, the real interest rate and Leu-Dollar exchange rate, while the Leu-Euro exchange rate is not. Akram and Das (2014) discovered the relationship between Japanese government bonds' (JGBs') nominal and short-term interest rates and other elements, such as low inflation and persistent deflationary pressures and tepid growth. Chionia s, Pragidis \& Schizas (2014) studied the influence of macroeconomic fundamentals and the underlying 10 years Greek government bonds. Their findings show that deficit, inflation, and unemployment play a more important role as determinants of the 10-year Greek bond yield. Hsing (2015) studied major components of demand and supply to examine the government bond yield in Spain using the EGARCH model, in the period from Q1 1999 to Q2 2014. Efthymiou (2016) analyses the macroeconomic determinants that affect Cyprus Sovereign Bonds Yields short-term changes over the Q1 2001 to the Q3 2015 by using an Autoregressive Model of one latent factor with Cochrane-Orcutt procedure. Akram and Das (2017) explored the long-term determinants of Indian government bonds' (IGB) nominal yields.

Apart from papers analyzing one country, there are also those that consider more countries by investigating the impact of individual variables on government bond yields. Inoguchi's (2007) primary aim was to find answers on two questions: whether government bond yields in Hong Kong, Singapore, and Thailand correlate with US government bond yields, and whether bonds in these Asian countries are influenced by ADB bond issues. In his paper, he used the EGARCH model. Claessens, Klingebiel \& Schmukler (2007) using panel data find that institutional and macroeconomic indicators are related to the depth and currency content of government bond markets. The results showed that smaller economies bear to have smaller domestic currency bond markets but have a larger volume of bond financing in foreign currency. Balli (2009), Aßmann \& Boysen-Hogrefe (2011, 2012), Baker, Carreras, Kirby \& Meaning (2016) and Akram \& Das (2017) focused their works on the eurozone. Balli by using GARCH model affirms that unlike other bond markets, in euro markets the credit risk and other macroeconomic and fiscal indicators are not capable of clarifying the sovereign bond yields after the beginning of monetary union. Aßmann \& 
Boysen-Hogrefe propose the use of latent processes to model the time variation present in the relationship between government bond spreads and determinants thereof. The model takes into account the high level of financial integration within the monetary union and assesses the correlation between government bonds yields of ten euro area countries and German government bond yields. Unlike them, Baker, Carreras, Kirby \& Meaning use the lens of expectations hypothesis adjusting for measures of risk. They also include a forwardlooking measure of expectations of overnight interest rates, as an instrument of ECB monetary policy, alongside debt-GDP in an error-correcting panel groundwork. Akram \& Das worked on the technique of the pooled mean group (PMG). Furthermore, autoregressive distributive lag (ARDL) methods are used to answer the same question for a single country. The results indicate that short-term interest rates are the most significant determinants of long-term government bonds' nominal yields.

Alexopoulou, Bunda \& Ferrando (2010) and Leonov \& Isaieva (2014) on the other side, have focused their analysis on the new EU members, except Leonov \& Isaieva also include Ukraine. Alexopoulou, Bunda \& Ferrando have used a dynamic panel error-correction model considering both: common long-run determinants and cross-country heterogeneities. Leonov \& Isaieva with PCA method on the three-component model consider the influence of government bond spread as a significant indicator of a country's financial market vulnerability.

Gruber \& Kamin (2012) examined the impact of fiscal positions on long-term government bond yields in the OECD. In a panel regression over the period from 1988 to 2007, they have found a powerful and important influence of fiscal performance on long-term bond yields. Žigman and Cota (2011) identify the influence of fiscal and non-fiscal factors of movements in spreads on government bonds in emerging markets using panel data for the period from 1Q 2003 to 2010On the contrary, Dimic, Kiviaho, Piljak \& Äijö (2016) examined the impact of global market uncertainty and domestic macroeconomic indicators on stockbond correlation in emerging markets. A wavelet analysis applies to 10 emerging markets namely Argentina, Brazil, Bulgaria, Colombia, Mexico, Peru, Philippines, Russia, Turkey, and Venezuela, in different time horizons.

Ichiue \& Shimizu (2012) explored the factors that influence the long-term bond yields through a panel data analysis of forward rates in Japan and US. Malešević Perović (2015) investigated the influence of government debt and primary balance on long-term government bond yields in the Central and Eastern European (CEE) countries in the period from 2000 - 2013. Gyódi (2017) in his analyses, which are also related to CEE countries, predict the pricing of sovereign risk and contagion during the crises.

Abad \& Chulia (2016) studied the movement of European government bond market contagion during the two periods: the financial crisis and throughout the European sovereign debt crisis. Further, they investigate the fundamental factors of the dynamics of contagion using an ordered logistic regression. The model reveals that interest rates, stock 
market returns, and market volatility support explain contagion in European government bond markets but, their applicability ranges from crisis to crisis.

Zaremba and Czapkiewicz (2017) in their study offer a four-factor pricing model for international government bonds which is based on four large return drivers in the fixedincome universe: volatility risk, credit risk, value effect, and momentum. The model explained the fluctuation of government bond returns and covered a range of crosssectional return patterns in government bond markets. A sample of research included 25 developed and emerging markets for period $1992-2016$.

\section{Methodology}

\subsection{Empirical Methodology}

The economy of every country is under the influence of different anomalous shocks that may have a significant impact on its' economic situation. The shocks can be caused by the political situation, changes in institutional arrangements, regime shifts, international disasters, changes in climate, economic crises, and variations in oil prices. Such unanticipated changes can cause structural breaks in the economic time series data, and they should be considered in econometric modeling and forecasting. Trends in economic data alter with phases of an economic, fiscal, social or political cycle, so it is crucial to identify structural breaks or changes since they enable multilevel analysis.

We might observe a "structural" break in the data (e.g., in Croatian economy there is pronounced growth slowdown after 2008, during the recession). In these cases there are sudden jumps or breaks in the data, it is continuous but contains an inflection point. Therefore, there are two distinct regression lines evident in the same data. The piecewise linear model consists of two separate straight line segments, which means that if we ran regressions for each of the distinct patterns in the data, we would get different results in the regressions.

The standard linear regression model estimates that the parameters of the model do not vary across observations. Despite this assumption, structural change, the changing of parameters at dates in the sample period, plays an empirically relevant role in applied time series analysis. We examine a standard multiple linear regression model with $\mathrm{T}$ periods and $\mathrm{m}$ potential breaks (producing $\mathrm{m}+1$ regimes). For the observations $\mathrm{Tj}, \mathrm{Tj}+1, \ldots, \mathrm{Tj}+1$ -1 in regime $\mathrm{j}$ we have the regression model

$$
y_{t}=X_{t}^{\prime} \beta+Z_{\mathrm{t}}^{\prime} \delta_{\mathrm{j}}+\epsilon_{\mathrm{t}}
$$

for the regimes $\mathrm{j}=0, \ldots, \mathrm{m}$. Note that the regressors are divided into two groups. The $X$ variables are those whose parameters do not vary across regimes, while the $Z$ variables have coefficients that are regime-specific. While it is slightly more conductive to define break dates to be the last date of a regime, we follow EViews's convention in 
defining the break date to be the first date of the subsequent regime. We tie down the endpoints by setting $\mathrm{T} 0=1$ and $\mathrm{Tm}+1=\mathrm{T}+1$.

Once the number and identity of the breakpoints are determined, the model may be estimated using standard regression techniques. We may rewrite the equation specification as a standard regression equation

$$
y_{t}=X_{t}^{\prime} \beta+\bar{Z}_{t}^{\prime} \bar{\delta}+\epsilon_{t}
$$

with fixed parameter vectors $\beta$ and $\bar{\delta}=\left(\delta_{0}^{\prime}, \delta_{1}^{\prime}, \ldots, \delta_{m}^{\prime}\right)$ where $\bar{Z} \mathrm{t}^{\prime}$ is an expanded set of regressors interacted with the set of dummy variables corresponding to each of the $\mathrm{m}+$ 1 regime segments.

\subsection{Data description}

In the paper, the sample comprises quarterly data on government bond yields and their potential determinants for the Croatian economy for the period 2001-2017. The model altogether observes 19 variables of which one is dependent - government bond yield, and the remaining are independent divided into several sets of variables as follow. The macroeconomic variables used in the model are the following: gross domestic product (GDP), harmonized index of consumer prices (HICP), unemployment and foreign direct investments (FDI). As far as the financial variables are concerned, the model includes the movement of the stock index of CROBEX, exchange rate HRK/EUR taken as the middle rate of Croatian National Bank, monetary aggregate $M 1$ and the reference interest rate EURIBOR. Except these, the model comprises a credit rating of the Republic of Croatia given by the three major companies S\&P, Moody's and Fitch. A variable is considered as dummy depending there was a change or not. A group of fiscal variables in this paper is primarily oriented to the public debt of the Republic of Croatia, which represents the sum of domestic and external debt. The following related variables are used: the ratio of domestic debt in the total debt of the general government, the ratio of domestic debt in GDP, the ratio of external debt in GDP and the ratio of total government debt in GDP. Also, the model combines the ratio of surplus in the GDP and the primary operating balance. The fourth set of variables is political. The model has observed election period, government change, new finance minister and political option which are represented as dummies. All variables used are explained in Table 2.

\section{Table 2 Data sources and definition}

\begin{tabular}{|c|l|c|}
\hline $\begin{array}{c}\text { Variable } \\
\text { (mnemonic) }\end{array}$ & Description & Source \\
\hline $\begin{array}{c}\text { Government bond } \\
\text { yield } \\
\text { (yield) }\end{array}$ & $\begin{array}{l}\text { Average quarterly yields to maturity on domestic and foreign } \\
\text { bonds of the Republic of Croatia are calculated as the average } \\
\text { monthly yields. Domestic bond yields are calculated by a } \\
\text { weighted average of the average trading price on all trading } \\
\text { segments of the Zagreb Stock Exchange. For foreign bonds, }\end{array}$ & Croatian National Bank \\
\hline
\end{tabular}




\begin{tabular}{|c|c|c|}
\hline & $\begin{array}{l}\text { yields to maturity are taken from the Bloomberg's financial } \\
\text { service and are calculated by daily data on the last bid } \\
\text { (quoted) price. }\end{array}$ & \\
\hline $\begin{array}{l}\text { Gross domestic } \\
\text { product } \\
\text { (gdp) }\end{array}$ & $\begin{array}{l}\text { The market value of all final goods and services produced in a } \\
\text { period. }\end{array}$ & $\begin{array}{l}\text { Croatian Bureau of } \\
\text { statistics, EUROSTAT }\end{array}$ \\
\hline $\begin{array}{l}\text { Harmonised Index of } \\
\text { Consumer Prices } \\
\text { (hicp) }\end{array}$ & $\begin{array}{l}\text { It measures the change over time in the prices of consumer } \\
\text { goods and services acquired, used or paid for by euro area } \\
\text { households. }\end{array}$ & Croatian National Bank \\
\hline $\begin{array}{l}\text { Unemployment rate } \\
\text { (unempl) }\end{array}$ & $\begin{array}{l}\text { The share of the working-age population who do not have a } \\
\text { permanent job but is actively looking it. }\end{array}$ & $\begin{array}{l}\text { Croatian Bureau of } \\
\text { statistics, EUROSTAT }\end{array}$ \\
\hline $\begin{array}{l}\text { Foreign Direct } \\
\text { Investments } \\
\text { (fdi) }\end{array}$ & $\begin{array}{l}\text { A part of the balance of payments, and include equity capital, } \\
\text { reinvested earnings and debt relations between ownership- } \\
\text { related residents and non-residents. }\end{array}$ & Croatian National Bank \\
\hline $\begin{array}{l}\text { Country rating } \\
\text { (rating) }\end{array}$ & $\begin{array}{l}\text { The government debt credit rating for the Republic of Croatia } \\
\text { as reported by major credit rating agencies used by sovereign } \\
\text { wealth funds, pension funds, and other investors to gauge the } \\
\text { creditworthiness of the Republic of Croatia. }\end{array}$ & Croatian National Bank \\
\hline $\begin{array}{l}\text { CROBEX } \\
\text { (crobex) }\end{array}$ & $\begin{array}{l}\text { The Zagreb Stock Exchange equity index, price index consists } \\
\text { of } 25 \text { shares, base value } 1000 \text {. }\end{array}$ & Zagreb Stock Exchange \\
\hline $\begin{array}{l}\text { Exchange rate } \\
\text { HRK/EURO } \\
\text { (exch) }\end{array}$ & Middle rate considered at the end of the quarter. & Croatian National Bank \\
\hline $\begin{array}{l}12 \text { EURIBOR } \\
\text { (euribor) }\end{array}$ & $\begin{array}{l}\text { The reference interest rate that is established on the European } \\
\text { interbank market for the euro currency. } 12 \text { EURIBOR means } \\
\text { lending in } 12 \text { months. }\end{array}$ & European Central Bank \\
\hline $\begin{array}{l}\text { Money (M1) } \\
\quad(\mathrm{m} 1)\end{array}$ & $\begin{array}{l}\text { It comprises currency outside credit institutions, deposits with } \\
\text { the CNB by other financial institutions as well as demand } \\
\text { deposits with credit institutions. }\end{array}$ & Croatian National Bank \\
\hline $\begin{array}{l}\text { Surplus (operating } \\
\text { balance) / GDP } \\
\text { (surplus) }\end{array}$ & $\begin{array}{l}\text { The ratio of the difference between the total revenues and } \\
\text { expenditures of the state in the GDP. }\end{array}$ & $\begin{array}{l}\text { The Republic of Croatia } \\
\text { - Ministry of finance }\end{array}$ \\
\hline $\begin{array}{l}\text { Domestic debt / } \\
\text { Public debt } \\
\text { (dom_pub) }\end{array}$ & The ratio of domestic debt to the total public debt. & $\begin{array}{l}\text { The Republic of Croatia } \\
\text { - Ministry of finance }\end{array}$ \\
\hline $\begin{array}{l}\text { Domestic debt / GDP } \\
\text { (dom_gdp) }\end{array}$ & The ratio of domestic debt in the GDP. & $\begin{array}{l}\text { The Republic of Croatia } \\
\text { - Ministry of finance }\end{array}$ \\
\hline $\begin{array}{l}\text { External debt / GDP } \\
\text { (ext_gdp) }\end{array}$ & The ratio of external debt in the GDP. & $\begin{array}{l}\text { The Republic of Croatia } \\
\text { - Ministry of finance }\end{array}$ \\
\hline $\begin{array}{l}\text { Public debt / GDP } \\
\text { (general) }\end{array}$ & The ratio of the total public debt in the GDP. & $\begin{array}{l}\text { The Republic of Croatia } \\
\text { - Ministry of finance }\end{array}$ \\
\hline $\begin{array}{l}\text { Election period } \\
\text { (election) }\end{array}$ & Dummy variable. Value 1 means it is; value 0 means it is not. & Author's estimate \\
\hline $\begin{array}{l}\text { Change of } \\
\text { government } \\
\text { (change) }\end{array}$ & Dummy variable. Value 1 means it is; value 0 means it is not. & Author's estimate \\
\hline $\begin{array}{l}\text { New finance minister } \\
\text { (treasury) }\end{array}$ & Dummy variable. Value 1 means it is; value 0 means it is not. & Author's estimate \\
\hline $\begin{array}{l}\text { Political option } \\
\text { (rightwing) }\end{array}$ & Dummy variable. Value 1 means it is; value 0 means it is not. & Author's estimate \\
\hline
\end{tabular}

Source: authors' work according to available sources 


\section{Results and discussion}

Before selecting independent variables, the descriptive statistics (Table A1) and the correlation matrix (Table A2) were studied to verify which variables would not violate the assumptions of linear regression. Based on the empirical values of the Jarque-Bera test, variables which do not satisfy the assumption of normality of distribution are excluded. This can be confirmed by the value of skewness and kurtosis also. Data were also tested using for heteroscedasticity and correlograms were inspected to detect potential autocorrelation problems. After omitting variables that do not fit with the necessary assumptions, correlation coefficients are observed to recognize determinants that can lead to multicollinearity in regression. Based on the correlation matrix, eight regression models have been estimated:

$$
\begin{aligned}
& \text { yield }=\beta_{0}+\beta_{1} * g d p+\beta_{2} * \text { unempl }+\beta_{3} * f d i+\beta_{4} * \text { euribor }+\beta_{5} * d o m \_p u b \\
& +\beta_{6} * \text { ext_gdp }+\beta_{7} * \text { election }+\beta_{8} * \text { change } \\
& \text { yield }=\beta_{0}+\beta_{1} * \text { hicp }+\beta_{2} * \text { rating }+\beta_{3} * \text { exch }+\beta_{4} * m 1+\beta_{5} * \text { surplus }+\beta_{6} \\
& * d o m_{-} g d p+\beta_{7} * \text { election }+\beta_{8} * \text { rightwing }+\beta_{9} * \text { treasury } \\
& \text { yield }=\beta_{0}+\beta_{1} * g d p+\beta_{2} * \text { unempl }+\beta_{3} * f d i+\beta_{4} * \text { euribor }+\beta_{5} * d o m \_p u b \\
& +\beta_{6} * \text { ext_gdp }+\beta_{7} * \text { election }+\beta_{8} * \text { change } \\
& \text { yield }=\beta_{0}+\beta_{1} * \text { hicp }+\beta_{2} * \text { rating }+\beta_{3} * \text { exch }+\beta_{4} * m 1+\beta_{5} * \text { surplus }+\beta_{6} \\
& * d o m_{-} g d p+\beta_{7} * \text { election }+\beta_{8} * \text { change }+\beta_{9} * \text { rightwing }+\beta_{10} \\
& \text { * treasury } \\
& +\beta_{6} * \text { ext_gdp }+\beta_{7} * \text { election } \\
& * \text { election }+\beta_{7} * \text { treasury } \\
& ++\beta_{6} * \text { ext_gdp }+\beta_{7} * \text { election }+\beta_{8} * \text { change } \\
& \text { yield }=\beta_{0}+\beta_{1} * \text { hicp }+\beta_{2} * \text { rating }+\beta_{3} * \text { exch }+\beta_{4} * m 1+\beta_{5} * \text { surplus }+\beta_{6} \\
& * \text { election }+\beta_{7} * \text { change }+\beta_{8} * \text { rightwing }+\beta_{9} * \text { treasury }
\end{aligned}
$$

Estimations have been split up into four different periods, as suggested by multiple breakpoint tests. The first part included the pre-crisis period (2001Q3-2008Q2), it is followed by the crisis period, which was divided into two sections: from 2008Q3-2012Q3 
and 2012Q4-2014Q4, whereas the last period included the period of quantitative easing and generally low-interest rates (2015Q1-2017Q4). Figure 1 presents structural changes in the dependent variable, yield.

\section{Figure 1 Actual, Fitted, and Residual Graph of yield}

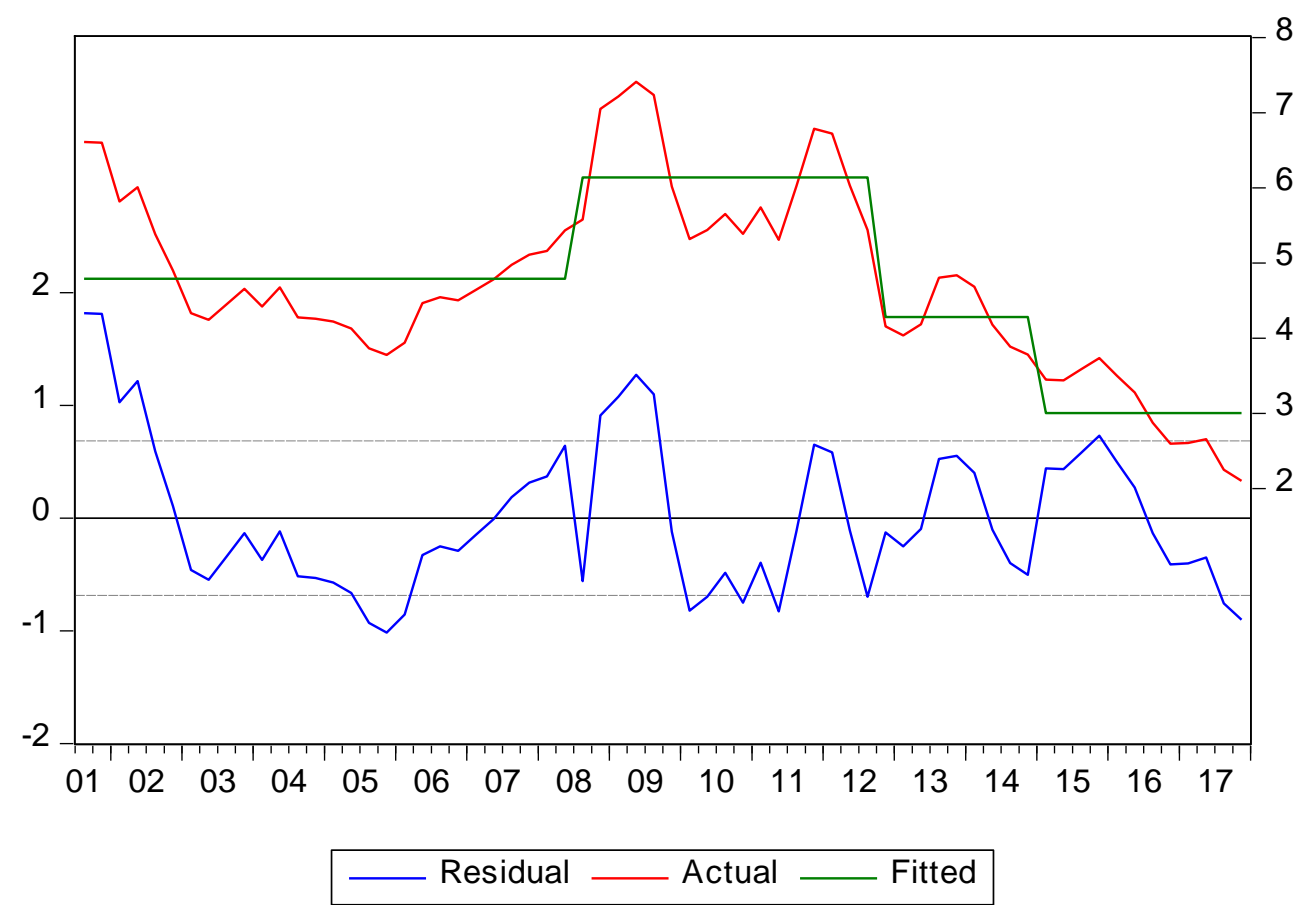

The summary of the results of all eight estimated models with the corresponding statistical values is given in Table 3.

Table 3 Regression Results of Estimated Models

\begin{tabular}{|c|c|c|c|c|c|c|c|c|}
\hline \multirow{2}{*}{ Variable } & \multicolumn{2}{|c|}{ 2001Q3-2008Q2 } & \multicolumn{2}{|c|}{ 2008Q3-2012Q3 } & \multicolumn{2}{|c|}{ 2012Q4-2014Q4 } & \multicolumn{2}{|c|}{ 2015Q1-2017Q4 } \\
\hline & (1) & (2) & (3) & (4) & (5) & (6) & (7) & (8) \\
\hline c & $\begin{array}{l}-3.0113 \\
(0.2457)\end{array}$ & $\begin{array}{l}22.1714 \\
(0.0508)\end{array}$ & $\begin{array}{c}6.5081 \\
(0.0000)\end{array}$ & $\begin{array}{l}-8.1152 \\
(0.2527)\end{array}$ & $\begin{array}{l}2.6595 \\
(0.0971)\end{array}$ & $\begin{array}{l}20.4947 \\
(0.2965)\end{array}$ & $\begin{array}{c}6.0316 \\
(0.0024)\end{array}$ & $\begin{array}{l}30.8583 \\
(0.0480)\end{array}$ \\
\hline gdp & $\begin{array}{c}-0.2313 \\
(0.0410)\end{array}$ & - & $\begin{array}{l}-0.1224 \\
(0.0390)\end{array}$ & - & $\begin{array}{l}-0.0952 \\
(0.1248)\end{array}$ & - & $\begin{array}{l}-0.0378 \\
(0.3725)\end{array}$ & 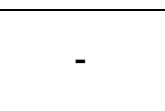 \\
\hline hicp & - & $\begin{array}{c}0.0419 \\
(0.6158)\end{array}$ & - & $\begin{array}{l}-0.3304 \\
(0.0006)\end{array}$ & 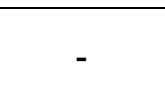 & $\begin{array}{c}0.0738 \\
(0.6451)\end{array}$ & - & $\begin{array}{l}-0.2100 \\
(0.0449)\end{array}$ \\
\hline unempl & $\begin{array}{c}\mathbf{0 . 6 6 0 8} \\
(0.0050)\end{array}$ & & $\begin{array}{l}-0.0565 \\
(0.4117)\end{array}$ & & $\begin{array}{c}\mathbf{0 . 3 1 2 3} \\
(0.0018)\end{array}$ & & $\begin{array}{c}\mathbf{0 . 1 0 4 8} \\
(0.0073)\end{array}$ & \\
\hline fdi & $\begin{array}{c}-0.00002 \\
(0.0050)\end{array}$ & - & $\begin{array}{l}\mathbf{0 . 0 0 0 0 4} \\
(0.0012)\end{array}$ & - & $\begin{array}{l}\mathbf{0 . 0 0 0 0 7} \\
(0.0023)\end{array}$ & - & $\begin{array}{c}\mathbf{0 . 0 0 0 2} \\
(0.0013)\end{array}$ & - \\
\hline rating & 1 & $\begin{array}{c}0.0011 \\
(0.9963)\end{array}$ & 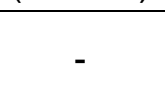 & $\begin{array}{c}\mathbf{0 . 6 8 4 7} \\
(0.0176)\end{array}$ & & - & 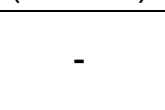 & $\begin{array}{c}0.0212 \\
(0.9032)\end{array}$ \\
\hline exch & - & $\begin{array}{l}-\mathbf{- 2 . 3 9 6 4} \\
(0.0286)\end{array}$ & - & $\begin{array}{c}4.6935 \\
(0.0898)\end{array}$ & - & $\begin{array}{c}-15.4582 \\
(0.0225)\end{array}$ & - & $\begin{array}{c}6.2353 \\
(0.0002)\end{array}$ \\
\hline
\end{tabular}




\begin{tabular}{|c|c|c|c|c|c|c|c|c|}
\hline euribor & $\begin{array}{c}\mathbf{0 . 7 8 0 9} \\
(0.0000)\end{array}$ & - & $\begin{array}{c}0.2143 \\
(0.1970)\end{array}$ & - & $\begin{array}{c}.9653 \\
(0.0185)\end{array}$ & - & $\begin{array}{c}1.1039 \\
(0.3387)\end{array}$ & - \\
\hline m1 & - & $\begin{array}{c}-2.45 E- \\
05 \\
(0.5220)\end{array}$ & - & $\begin{array}{c}-2.28 E- \\
05 \\
(0.7531)\end{array}$ & - & $\begin{array}{c}-0.00004 \\
(0.0151)\end{array}$ & - & $\begin{array}{c}-4.01 \mathrm{E}- \\
05 \\
(0.0001)\end{array}$ \\
\hline surplus & - & $\begin{array}{c}5.8044 \\
(0.1628)\end{array}$ & - & $\begin{array}{l}-3.7837 \\
(0.6820)\end{array}$ & - & $\begin{array}{c}2.4790 \\
(0.5558)\end{array}$ & - & $\begin{array}{c}7.9186 \\
(0.0079)\end{array}$ \\
\hline dom_gdp & - & $\begin{array}{c}-26.2314 \\
(0.0008)\end{array}$ & - & $\begin{array}{l}-5.4359 \\
(0.0326)\end{array}$ & - & $\begin{array}{l}61.4961 \\
(0.0180)\end{array}$ & - & - \\
\hline dom_pub & $\begin{array}{l}-19.607 \\
(0.0000)\end{array}$ & - & $\begin{array}{c}2.5387 \\
(0.6220)\end{array}$ & - & $\begin{array}{c}4.3830 \\
(0.6917)\end{array}$ & - & - & - \\
\hline ext_gdp & $\begin{array}{l}-36.949 \\
(0.0007)\end{array}$ & - & $\begin{array}{r}-15.2860 \\
(0.0139)\end{array}$ & - & $\begin{array}{l}-2.7817 \\
(0.3332)\end{array}$ & - & $\begin{array}{c}15.9499 \\
(0.0026)\end{array}$ & - \\
\hline election & $\begin{array}{l}-0.7945 \\
(0.0852)\end{array}$ & $\begin{array}{c}0.5383 \\
(0.1605)\end{array}$ & $\begin{array}{l}-0.0616 \\
(0.8751)\end{array}$ & $\begin{array}{c}0.0844 \\
(0.8147)\end{array}$ & $\begin{array}{l}-0.3357 \\
(0.0329)\end{array}$ & $\begin{array}{l}-0.3574 \\
(0.0785)\end{array}$ & $\begin{array}{c}\mathbf{0 . 2 1 8 9} \\
(0.0321)\end{array}$ & $\begin{array}{c}0.3317 \\
(0.0566)\end{array}$ \\
\hline change & $\begin{array}{c}0.8676 \\
(0.3046)\end{array}$ & - & $\begin{array}{c}0.8040 \\
(0.1333)\end{array}$ & $\begin{array}{c}1.3583 \\
(0.0547)\end{array}$ & - & - & $\begin{array}{l}-0.0578 \\
(0.5876)\end{array}$ & $\begin{array}{l}-0.2483 \\
(0.5924)\end{array}$ \\
\hline rightwing & - & $\begin{array}{l}-0.3890 \\
(0.3206)\end{array}$ & - & $\begin{array}{l}-1.1281 \\
(0.1719)\end{array}$ & - & - & - & $\begin{array}{l}-0.5628 \\
(0.1520)\end{array}$ \\
\hline treasury & - & $\begin{array}{l}-0.4212 \\
(0.5929)\end{array}$ & - & $\begin{array}{l}-1.0126 \\
(0.0214)\end{array}$ & - & $\begin{array}{c}-0.8574 \\
(0.0517)\end{array}$ & - & $\begin{array}{c}0.3534 \\
(0.3900)\end{array}$ \\
\hline $\mathbf{R}^{2}$ & 0.4276 & 0.7299 & 0.5135 & 0.8457 & 0.7815 & 0.9649 & 0.8131 & 0.9272 \\
\hline Obs. & 28 & 28 & 17 & 17 & 9 & 9 & 12 & 12 \\
\hline
\end{tabular}

Note: $p$-values are given in the parentheses.

The increase in gross domestic product (GDP) as a fundamental indicator of economic growth has a positive impact on all aspects of the economy and consequently on the price of borrowing. GDP growth will lower the costs of government borrowing and in that case yields on government bonds should have a downward trend. There is a visible negative link between observed variables in the period before the crisis and during the crisis. In the other two structural periods, this variable was not significant. On the other hand, the harmonized index of consumer price (HICP) as an indicator of the annual inflation rate and unemployment should have a proportional trend with government bond yields, as higher inflation and higher unemployment rate lead to worse economic conditions, increased instability and hence rising borrowing prices. However, the analysis revealed that HICP was significant as a determinant of government bonds yield in the second (crisis) period and fourth (recovery) period, but with a negative sign. The increase of FDI suggests an increase in investor confidence which reflects the positive perception of the country as a stable country suitable for investments both from the aspect of the investor and from the aspect of the creditor or lender what will reduce the price of the debt. According to the results, FDl's are significant determinant through the entire analyzed period, but only in the period before the crisis, its' growth affected the decline in yields on government bonds. Country's rating which measures the credit value of a country, and should have a 
substantial influence on the country's borrowing costs, was significant only in the crisis period which means that just in the period of financial instability, lack of liquidity and general skepticism, the investors turned to rating agencies to determine price of a debt.

Exchange rate, i.e. the appreciation of HRK in this context should mean the situation of strengthening the production and the overall economy. Keeping this in mind, the HRK/EUR exchange rate should be positively correlated with yields on government bonds. The only period with this significant positive correlation when the reduction in exchange rates had the effect of reducing the yield on government bonds, was the last period, a period of recovery. The EURIBOR as a benchmark interest rate on the interbank market has a positive trend with all interest rates, as well as interest rates on government bonds. Accordingly, and as can be seen in Table 3, the growth of EURIBOR increases the yield on government bonds in the Republic of Croatia. The growth of the monetary aggregate M1 in the basic means the situation of increased liquidity in the economy and the surplus of the funds. Consequently, it will reduce borrowing, so that the growth of the monetary aggregate will reduce yields on government bonds. There is a noticeable negative link between observed variables for the Republic of Croatia in the periods after 2012.

The share of surpluses in GDP means a situation where revenues are higher than expenditures, hence the need for borrowing is lower. Therefore the borrowing price will be low, i.e., yields on government bonds will decrease. This variable is significant only in the last period but shows a positive connection with bond yields. The share of domestic debt in GDP and external debt in GDP are significant variables in three analyzed periods unlike the share of domestic debt in total public debt, which was significant only before the crisis. The influences of the share of domestic and external debt in GDP are ambiguous and depend on the other external factors. Before crisis and in the first period of the crisis they show a negative correlation with bond yields and later they are positively correlated. The latter indicates that the increase in demand will increase the price of borrowing, so the yield on government bonds will also grow.

From selected political variables, the significant variables are elections in all periods except crisis and the change of the minister of finance (treasury) in the period from 2008Q3 to 2014Q4. Until 2015 elections had a negative influence on the price of debt as well as the treasury, which means that every change increased yields on a government bond. In the last period where there were two elections for the parliament, the correlation is positive indicating a decrease in the borrowing price.

\section{Conclusion}

Government securities, especially domestic, have an essential role in the development and functioning of the financial system due to the absorption of savings and the mechanism of financing the continued deficits. Among issued securities, the ones with the lowest risk of the issuer are government bonds. Their yields represent reference rates in determining the prices of corporate bonds and other financial instruments. Government bonds are not 
secured by any type of property but are based on the trust and credible investors' value these issues as low-risk.

Since 1996 the Republic of Croatia issued 57 bonds on domestic and foreign markets denominated in USD, ESP, EUR, JPY and HRK with interest rates ranging from $1,23 \%$ to $8,5 \%$. The longest maturity is 15 years, and there are 21 bonds on the market. Currently, there are more bonds on the foreign markets than on the domestic, but in the last three years, the Republic of Croatia turned to domestic borrowing which was in some cases cheaper than foreign.

To determine which variables had an influence on the price of debt in the period from 2001Q3 to 2017Q4, the authors divided this period into four sub-periods according to the structural breaks. Sudden events can cause breaks in economic data and results can variate based on those breaks since economic data reflect different trends and pattern under different unforeseen events. Structural breaks were identified based on the data for government bond yield. In the analysis, as possible determinants of yield, authors included 19 variables grouped in four categories: macroeconomic, financial, fiscal and political. Based on the structural breaks and correlation matrix, eight regression models were estimated.

Based on the conducted analysis we can conclude that structural breaks in the government bond yields in the Republic of Croatia are mainly related with changes caused by the economic crisis, and accession to the EU in 2013 did not have significant influence. Regression analysis showed that on the changes in government bond yields in the period before the crisis the most considerable influence had the macroeconomic and fiscal variables. During the crisis country's rating was taken into consideration along with macroeconomic and fiscal variables. In the second period of the crisis, more significant are financial and political variables, and in the recovery period the most significant became macroeconomic variables, but the influence of the remaining variables in the model has to be taken into account. 


\section{Appendix}

\section{A1 Initial descriptive statistics}

\begin{tabular}{|c|c|c|c|c|c|c|c|}
\hline & CHANGE & CROBEX & DOM_GDP & DOM_PUB & ELECTION & EURIBOR & EXCH \\
\hline Mean & 0.075758 & 2031.380 & 0.309796 & 0.531335 & 0.227273 & 1.914227 & 7.446081 \\
\hline Median & 0.000000 & 1810.830 & 0.259129 & 0.556282 & 0.000000 & 1.965000 & 7.442024 \\
\hline Maximum & 1.000000 & 5239.000 & 0.523201 & 0.639446 & 1.000000 & 5.495000 & 7.692318 \\
\hline Minimum & 0.000000 & 937.0900 & 0.131772 & 0.353559 & 0.000000 & -0.191000 & 7.107741 \\
\hline Std. Dev. & 0.266638 & 919.3705 & 0.141321 & 0.072788 & 0.422282 & 1.562637 & 0.136508 \\
\hline Skewness & 3.206551 & 1.930858 & 0.284620 & -0.698788 & 1.301583 & 0.467083 & -0.063560 \\
\hline Kurtosis & 11.28197 & 6.633468 & 1.431654 & 2.389537 & 2.694118 & 2.282494 & 2.185454 \\
\hline Jarque-Bera & 301.7268 & 77.31608 & 7.655289 & 6.396184 & 18.89260 & 3.815569 & 1.869025 \\
\hline Probability & 0.000000 & 0.000000 & 0.021761 & 0.040840 & 0.000079 & 0.148409 & 0.392777 \\
\hline Sum & 5.000000 & 134071.1 & 20.44652 & 35.06811 & 15.00000 & 126.3390 & 491.4413 \\
\hline Sum Sq. Dev. & 4.621212 & 54940740 & 1.298160 & 0.344378 & 11.59091 & 158.7193 & 1.211243 \\
\hline Observations & 66 & 66 & 66 & 66 & 66 & 66 & 66 \\
\hline & EXT_GDP & FDI & RATING & GDP & GENERAL & HICP & M1 \\
\hline Mean & 0.251770 & -15499.59 & 0.318182 & 1.777450 & 0.561565 & 89.52061 & 50802.17 \\
\hline Median & 0.228946 & -18572.90 & 0.000000 & 2.992843 & 0.477935 & 91.81167 & 49936.02 \\
\hline Maximum & 0.368628 & -2287.466 & 1.000000 & 6.641685 & 0.873559 & 101.2200 & 99436.26 \\
\hline Minimum & 0.176679 & -25797.54 & 0.000000 & -8.614260 & 0.346026 & 72.58333 & 20279.78 \\
\hline Std. Dev. & 0.060785 & 6886.031 & 0.469340 & 3.551615 & 0.198376 & 9.767546 & 17062.29 \\
\hline Skewness & 0.454124 & 0.763232 & 0.780720 & -0.621015 & 0.368600 & -0.337397 & 0.747503 \\
\hline Kurtosis & 1.839093 & 2.139490 & 1.609524 & 2.570486 & 1.431319 & 1.616898 & 3.531158 \\
\hline Jarque-Bera & 5.974698 & 8.444069 & 12.02168 & 4.749579 & 8.261617 & 6.512872 & 6.922227 \\
\hline Probability & 0.050421 & 0.014669 & 0.002452 & 0.093034 & 0.016070 & 0.038525 & 0.031395 \\
\hline Sum & 16.61679 & -1022973. & 21.00000 & 117.3117 & 37.06331 & 5908.360 & 3352943. \\
\hline Sum Sq. Dev. & 0.240165 & $3.08 \mathrm{E}+09$ & 14.31818 & 819.9082 & 2.557953 & 6201.322 & $1.89 \mathrm{E}+10$ \\
\hline Observations & 66 & 66 & 66 & 66 & 66 & 66 & 66 \\
\hline & RIGHTWING & SURPLUS & TREASURY & UNEMPL & $\begin{array}{l}\text { YIELD } \\
\end{array}$ & & \\
\hline Mean & 0.621212 & -0.018028 & 0.075758 & 13.74848 & 4.745044 & & \\
\hline Median & 1.000000 & -0.017885 & 0.000000 & 13.85000 & 4.650864 & & \\
\hline Maximum & 1.000000 & 0.036740 & 1.000000 & 22.20000 & 7.410417 & & \\
\hline Minimum & 0.000000 & -0.092884 & 0.000000 & 7.000000 & 2.102941 & & \\
\hline Std. Dev. & 0.488802 & 0.031341 & 0.266638 & 3.411395 & 1.242477 & & \\
\hline Skewness & -0.499756 & -0.285061 & 3.206551 & 0.360432 & 0.143174 & & \\
\hline Kurtosis & 1.249756 & 2.432207 & 11.28197 & 2.879895 & 2.670428 & & \\
\hline Jarque-Bera & 11.17154 & 1.780429 & 301.7268 & 1.468696 & 0.524184 & & \\
\hline Probability & 0.003751 & 0.410568 & 0.000000 & 0.479818 & 0.769440 & & \\
\hline Sum & 41.00000 & -1.189848 & 5.000000 & 907.4000 & 313.1729 & & \\
\hline Sum Sq. Dev. & 15.53030 & 0.063845 & 4.621212 & 756.4448 & 100.3437 & & \\
\hline Observations & 66 & 66 & 66 & 66 & 66 & & \\
\hline
\end{tabular}




\section{A2 Correlation Matrix}

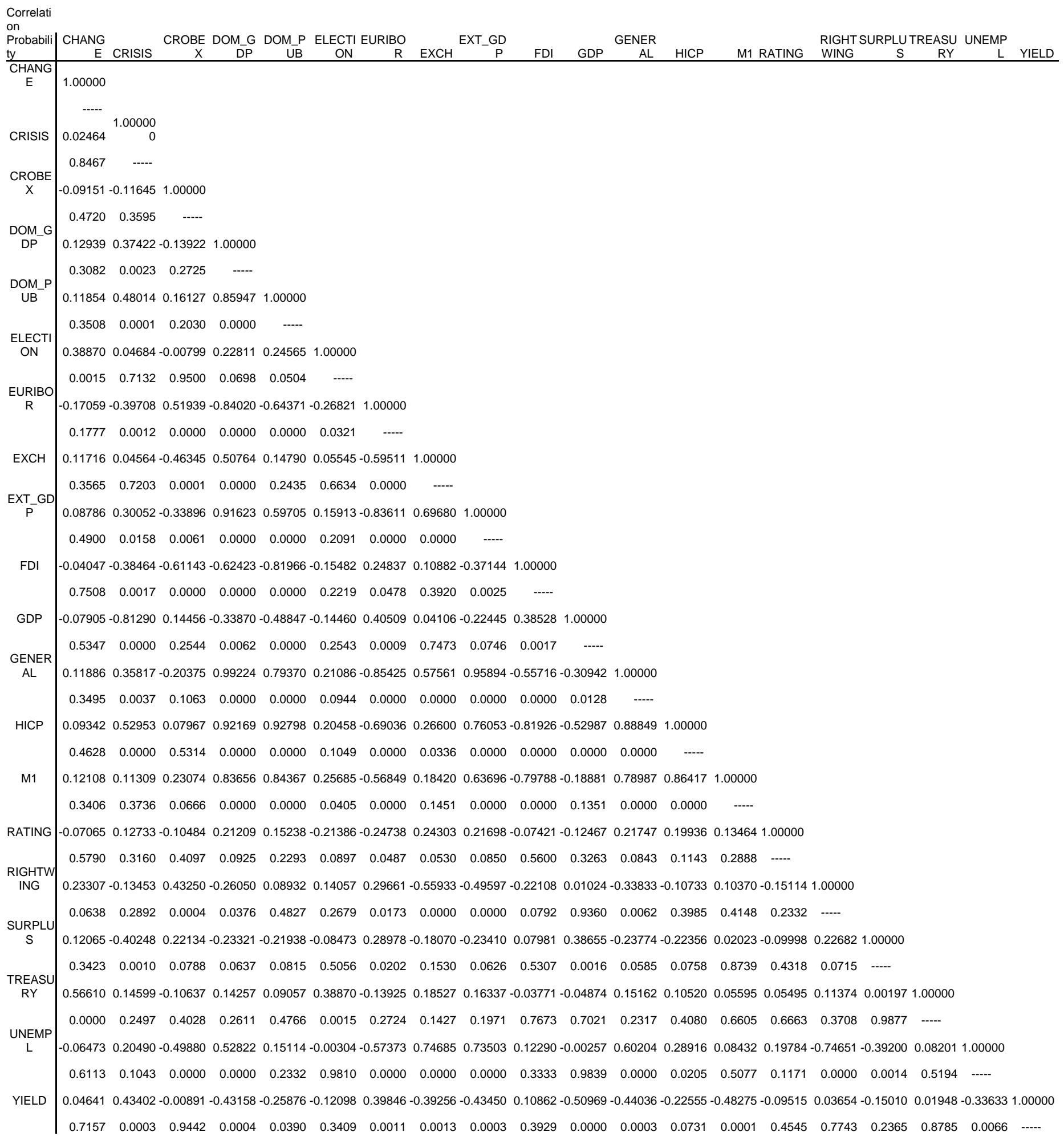




\section{References}

Abad, P. \& Chulia, H. 2016, "European Government Bond Market Contagion in Turbulent Times", Finance A Uver-Czech Journal of Economics and Finance, vol. 66, no. 3, pp. 263-276.

Akram, T. \& Das, A. 2014, "The determinants of long-term Japanese government bonds' low nominal yields", Working Paper, Levy Economics Institute, vol. 818.

Akram, T. \& Das, A. 2017, "The Dynamics of Government Bond Yields in the Euro Zone", Annals of Financial Economics, vol. 12, no. 3.

Akram, T. \& Das, A. 2017, The long-run determinants of Indian government bond yields, Levy Economics Institute, Annandale-on-Hudson, NY.

Alexopoulou, I., Bunda, I. \& Ferrando, A. 2010, "Determinants of Government Bond Spreads in New EU Countries", Eastern European Economics, vol. 48, no. 5, pp. 5-37.

Aßmann, C. \& Boysen-Hogrefe, J. 2012;2011; "Determinants of government bond spreads in the euro area: in good times as in bad", Empirica, vol. 39, no. 3, pp. 341-356.

Baker, J., Carreras, O., Kirby, S., \& Meaning, J. (2016). The fiscal and monetary determinants of sovereign bond yields in the Euro Area (No. 466). National Institute of Economic and Social Research.

Balli, F. 2009, "Spillover effects on government bond yields in the euro zone. Does full financial integration exist in European government bond markets?", Journal of Economics and Finance, vol. 33, no. 4, pp.331-363.

Chionis, D., Pragidis, I. \& Schizas, P. 2014, "Long-term government bond yields and macroeconomic fundamentals: Evidence for Greece during the crisis-era", Finance Research Letters, vol. 11, no. 3, pp. 254-258.

Claessens, S., Klingebiel, D. \& Schmukler, S.L. 2007, "Government Bonds in Domestic and Foreign Currency: the Role of Institutional and Macroeconomic Factors", Review of International Economics, vol. 15, no. 2, pp. 370-413.

Croatian National Bank: http://www.hnb.hr/en/

Dimic, N., Kiviaho, J., Piljak, V., \& Äijö, J. (2016). Impact of financial market uncertainty and macroeconomic factors on stock-bond correlation in emerging markets. Research in International Business and Finance, 36, 41-51.

Dragič, K., \& Lamza, D. (2004). Determinants of Designing the Government Securities Domestic Market. Ekonomski pregled, 55(11-12), 967-1001.

EFTHYMIOU, X. (2016). THE MACROECONOMIC FACTORS THAT AFFECT IN THE SHORT-TERM THE CYPRUS SOVEREIGN BOND YIELDS.

European Central Bank: http://www.ecb.europa.eu/home/html/index.en.html

EUROSTAT: http://ec.europa.eu/eurostat/

Gruber, J. W., \& Kamin, S. B. (2012). Fiscal positions and government bond yields in OECD countries. Journal of Money, Credit and Banking, 44(8), 1563-1587.

Gyódi, K. 2017, "Determinants of CEE government bond spreads and contagion between 2001-2014", Acta oeconomica, vol. 67 , no. 2, pp. 235-256.

HANFA (2010)., Quarterly bulletin, vol. II/2010., no 9., pp.7-15. 
Hsing, Y. 2015, "Determinants of the Government Bond Yield in Spain: A Loanable Funds Model", International Journal of Financial Studies, vol. 3, no. 3, pp. 342-350.

Ichiue, H., \& Shimizu, Y. (2012). Determinants of long-term yields: A panel data analysis of major countries and decomposition of yields of Japan and the US (No. 12-E-7). Bank of Japan.

Inoguchi, M. (2007). Influence of ADB bond issues and US bonds on Asian government bonds. Asian Economic Journal, 21(4), 387-404.

Leonov, S.V. \& Isaieva, O.V. 2014, "Determinants of government bond spreads in Ukraine and new EU members", Actual Problems of Economics, vol. 155, no. 5, pp. 416-425.

Malešević Perović, L. 2015, "The impact of fiscal positions on government bond yields in CEE countries", Economic Systems, vol. 39, no. 2, pp. 301-316.

Pirtea, M., Nicolescu, A. \& Mota, P. 2013, "An Empirical Study on Public Debt's Determinants: Evidence from Romania", Transylvanian Review of Administrative Sciences, no. 38E, pp. 144-157.

Poghosyan, T. (2014). Long-run and short-run determinants of sovereign bond yields in advanced economies. Economic Systems, 38(1), 100-114.

Prohaska, Z., \& Draženović, B. O. (2010, January). Development of government bonds market in Croatia. In 5th International Conference: An Enterprise Odyssey: From Crisis to Prosperity-Challenges for Government and Business.

The Republic of Croatia - Ministry of finance: http://www.mfin.hr/en

Zagreb Stock Exchange: http://www.zse.hr/

Zaremba, A., \& Czapkiewicz, A. (2017). The cross section of international government bond returns. Economic Modelling, 66, 171-183.

Žigman, A. \& Cota, B. 2011, "The impact of fiscal policy on government bond spreads in emerging markets", Financial Theory and Practice, vol. 35, no. 4, pp. 385-412. 